\title{
Cocoa Purchasing and the Issue of Insecurity in the Akontombra District in the Western Region of Ghana
}

\author{
Jacob Obodai ${ }^{*}$, Paul Kitson Baffour Asamoah ${ }^{2)}$ and Joseph Edusei ${ }^{2)}$ \\ ${ }^{1)}$ Department of Planning and Development Studies, Christian Service University College \\ ${ }^{2}$ Centre for Settlements Studies, College of Art and Built Environment, \\ Kwame Nkrumah University of Science and Technology, Kumasi-Ghana \\ ${ }^{*}$ Corresponding Author: jacobobodai@gmail.com \\ Received: 12 February 2018 / Accepted: 2 April 2018
}

\begin{abstract}
The cocoa industry in Ghana is plagued with a number of challenges. Among such challenges is the issue of insecurity. This notwithstanding, there are limited scholarly findings on the nature and the underlying factors associated with these insecurity issues. This paper examined the cocoa industry in the Sefwi Akontombra District in the Western Region of Ghana and presents an analysis of the processes and procedures for cocoa purchasing in the district; the security arrangements and mechanisms put in place during cocoa purchasing peak periods; the nature of access roads in cocoa growing areas in the district; and the influence of access roads on the insecurity of cocoa purchasing in the district. The study adopted a qualitative research approach and using a cross sectional study design, the case of OLAM Ghana Limited, a private licensed cocoa buying company operating in Sefwi Akontombra was examined. Primary data were gathered from purchasing clerks, drivers, warehouse keepers and officials of the company. Data from the District Command of the Ghana Police Service and the Department of Feeder Roads district office were solicited using interview guides. Non-participant observation and taking of photography were also employed as data capturing mechanism during the study. The study espoused content analysis in analysing the contents of the interviews and observational field notes in order to identify the main themes that emerge from the responses given by the respondents or the observation notes made. Inferences and implications were drawn then drawn from the analysis. The study found out that there was no security measure by OLAM Ghana Limited to ensure the safety of funds meant for cocoa buying, the storage and the transportation of cocoa beans in the study district. There was also no security arrangement during peak cocoa purchasing periods in the study district by key stakeholders within the cocoa sector in the district. Moreover, access road was further found out to be a major factor that accounts for some of the insecurity issues associated with cocoa purchasing activities in the Sefwi Akontombra District. The study thus recommends the development and adoption of security arrangements and mechanism by all stakeholders within the cocoa industry in the study district and the making of security issues a top priority by OLAM Ghana Limited.
\end{abstract}

Keywords: Cocoa; cocoa storage; feeder roads; insecurity, purchasing 


\section{INTRODUCTION}

Cocoa (Theobroma cacao) is an important agricultural commodity on the world market and a major cash crop in tropical regions. Its usefulness as a raw material for chocolate, which is consumed internationally, gives the commodity some form of relevance. About three million tons of cocoa beans are consumed annually (WCF, 2014). The bulk of the cocoa consumed on the world market comes from Africa. Statistics from the WCF (2014) indicates that Africa accounts for $68 \%$ of the total cocoa production in the world with a greater proportion of these supplies coming from the West African sub region. Cote d'Ivoire, the leading producer of cocoa on the world, accounts for $33 \%$ of the total cocoa beans followed by Ghana which accounts for $21 \%$ of the total beans on the world market (SWAC/OECD, 2011).

The cocoa sector within the West African sub-region contributes significantly to the socio-economic development of the countries where it is produced. The cash crop is the highest foreign exchange earner for most of the producing countries and employs substantial number of the total population in these countries (Afoakwa, 2014; GAIN, 2012 cited in Asante-Poku \& Angelucci, 2013; Asante et al., 2000). Notwithstanding, the cocoa sector within the West African sub-region is confronted with a number of challenges of which the issues of insecurity is crucial. Purchasing clerks (PCs) and haulage truck drivers are increasingly becoming vulnerable to thieves and armed robbers. The complex and interdependent relationship that exist between cocoa farmers and purchasing clerks in cocoa growing areas further exacerbate the insecurity issues associated with the purchase of the commodity.

Despite the emerging insecurity issues confronting the cocoa sector within the West African sub-region, studies detailing out the nature of the insecurity issues, factors contributing to these issues and recommendations on how to deal with the insecurity issues threatening the cocoa sector have not been fully researched into. Existing literature on the cocoa sector within the West African sub-region are mainly on the relationships between cocoa farmers and PCs, diseases affecting cocoa production, marketing and finance for cocoa industry among others (Anang et al., 2013; Dzene, 2010; Lundstedt \& Pärssinen, 2009; Ogunleye \& Oladeji, 2007; Laven \& Baud, 2007; Asamoah \& Baah, 2003). The effect of insecurity on the level of cocoa purchasing has not been empirically examined.

This exploratory study therefore seeks to bridge this gap in knowledge by investigating: (i) the processes and procedures for cocoa purchasing in the Sefwi Akontombra District of the Western Region, Ghana; (ii) the nature of insecurity and arrangements and mechanisms put in place during cocoa purchasing peak periods; (iii) the nature of access roads in cocoa growing areas in the district; and (iv) the relationship between access roads and insecurity of cocoa purchasing in the district. The study of insecurity associated with cocoa purchasing in the Sefwi Akontombra District aimed at finding remedies to the identified factors underlying the insecurity issues is commendable.

\section{Concept of Security}

The concept of security is an 'essentially contested concept (Gallie, 1956; Buzan, 1983). There is no consensus among scholars regarding the concept though most definitions of the concept tend to refer to a form of threat to cherished values (Williams, 2008). Distinction in security from an objective (absence of threats) and subjective point of view (absence of fear) as expounded by Wolfers (1962), are acknowledged in security 
literature (Schäfer, 2013; Baldwin, 1997). State centred and human centred typologies of security are also acknowledged in literature (Schäfer, 2013; UNDP, 1994) with more emphasis currently been placed on human centred security which is believed to result in national security and sustainable development. Human security was coined by the United Nations Development Programme (UNDP) in its 1994 Human Development Report. According to the UNDP (1994), seven dimensions of human security can be identified:

- economic security-assuring every individual a minimum requisite income;

- food security-the guarantee of physical and economic access to basic foodstuffs;

- health security-the guarantee of minimum protection from disease and unhealthy lifestyles;

- environmental security-protecting people from the short- and long-term ravages of nature, man-made threats in nature, and deterioration of the natural environment;

- personal security-protecting people from physical violence;

- community security-protecting people from loss of traditional relationships and values and from sectarian and ethnic violence; and

- political security-ensuring that people live in a society that honours their basic human rights (UNDP, 1994).

The literature outlines seven (7) dimension of security. These dimensions do not actually address all the security concerns. The study therefore identified an eighth dimension of security which is storage and haulage of goods and services. The concern of this study is income security which fits perfectly into UNDP's economic security, and the security of storage and haulage of cocoa beans.

\section{MATERIALS AND METHODS}

The study adopted a qualitative research approach (Creswell \& Design, 2008). The cross-sectional study design was espoused using OLAM Ghana Limited (OGL), a private licensed cocoa buying company (LBC) operating in the study area as a case study. The purposive sampling technique, considered adequate for qualitative and exploratory study was used in the selection of the key informants for the study. Twenty-eight PCs out of a total of thirty-eight PCs of OGL participated in the study. The intent of the study was to select all the PCs of OGL, however, only the twenty-eight PCs were available and willing to be part of the study since the study was conducted during the off-cocoa season. In addition, data were gathered from the district manager, district warehouse officer and two drivers of OGL. Information from the District Command of Ghana Police and the District Department of Works was also solicited. An interview guide was used in soliciting information from the key informants. With the permission from the participants, the interviews were recorded digitally for word-perfect transcription into word files. Observation and photograph of sections of roads linking some of the cocoa growing towns were undertaken. The personal consent of every respondent to participate in the study was sought. Participation in the study was also voluntary and every participant was assured the right to withdraw from the interview at any time or to decline answering certain questions if they do not wish to answer. Content analysis was espoused for this study in analysing the contents of the interviews and observational field notes in order to identify the main themes that emerge from the responses given by the respondents or the observation notes made (Kumar, 2011). Inferences and implications were then drawn from the analysis. 


\section{Profile of the Study Area}

This study investigated the insecurity issues associated with cocoa purchasing in the Sefwi Akontombra District of the Western Region, Ghana (Figure 1). The district lies in the North-Eastern part of the Western Region between Latitudes $6^{\circ} \mathrm{N}$ and $6^{\circ} 30^{\prime}$ $\mathrm{N}$ and Longitudes $2^{\circ} 45^{\prime} \mathrm{W}$ and $2^{\circ} 15^{\prime} \mathrm{W}$. The district covers an area of 1,120 sq.km, representing 3\% of the land area of the Western Region and has Akontombra as its district capital (GSS, 2014). About $86.6 \%$ of the total households of the district are engaged in agriculture with most of these households (99.3\%) engaged in crop farming (GSS, 2014). The district is the second largest producer of cocoa in the Western Region and produces nearly 6,000 metric tons of cocoa annually (GSS, 2014). The district falls within the tropical rainforest climate zone with high temperatures $\left(25^{\circ} \mathrm{C}-30^{\circ} \mathrm{C}\right)$ and moderate to heavy rainfall between $1,524 \mathrm{~mm}$ and 1,780 mm per annum (GSS, 2014).

\section{RESULTS AND DISCUSSION}

\section{Purchasing Cocoa Processes}

Cocoa purchasing arrangement in the Sefwi Akontombra district is similar to what pertains in most cocoa growing districts in Ghana. The services of PCs are engaged on commission basis equal to a fixed percentage per cocoa bag by Licensed Cocoa Buying Companies [LBCs] to purchase the cocoa bean directly from farmers in the district (Laven \& Baud, 2007; Lundstedt \& Pärssinen, 2009). During cocoa harvesting seasons, the PCs of OGL request for funds from the company to purchase cocoa beans from the farmers. Each PC receives a lump sum average of $\mathrm{GH} \not 21,250$ a week in a typical cocoa purchasing season. These funds are directly sent into the bank account of the individual PCs or via their district manager. This system results in the transfer of huge sum of money. Currently there is only one commercial bank [Home Finance Company

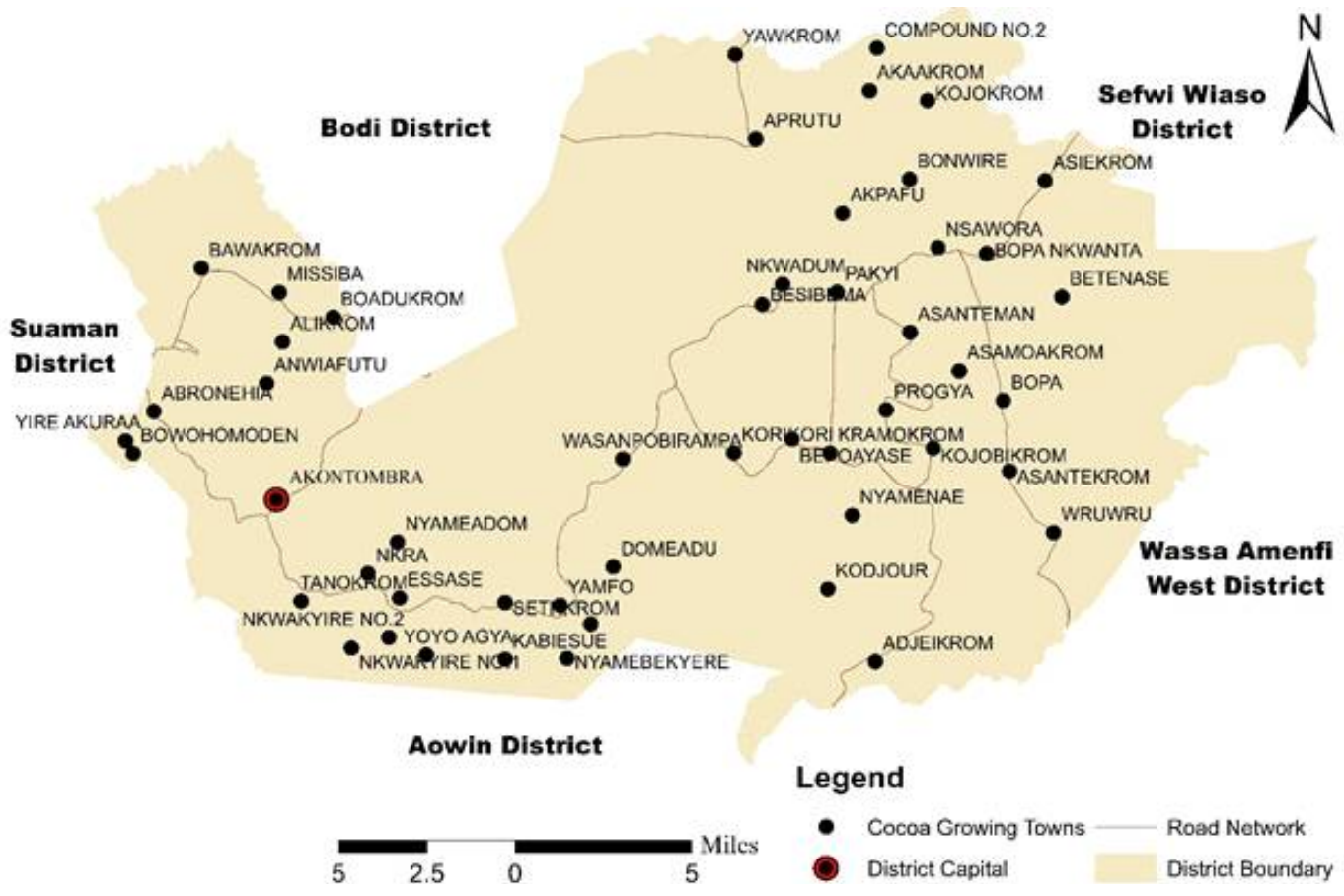

Figure 1. Sefwi Akontombra District. Source: Authors' Construct, 2016, GIS 
(HFC) Bank] operating in the district where approximately $15 \%$ of the $\mathrm{PCs}$ receive funds from. The remaining $85 \%$ of the $\mathrm{PCs}$ receive their funds from either the district manager or from the Ghana Commercial Bank in Wiawso. Both the HFC Bank and the Ghana Commercial Bank serve only as a medium through, which PCs receive funds. These monies are kept by the PCs in their respective homes before they are sent to their stations where they purchase the cocoa beans. The stations where PCs operate are mostly far from the district capital and they have to always travel with such huge sums of money on them without any security.

It can be inferred from the data that there is no security measure by OGL to ensure the safety of funds meant for cocoa purchasing. This puts the PCs at great risk and accounts for some of the insecurity issues associated with cocoa purchasing in the district. The absence of security measure of the company can be attributed to the lack of attention on the part of the leadership of OGL to the risk associated with the huge amounts of funds transferred directly to the PCs or through the district managers.

\section{Insecurity Issues Nature}

The type of insecurity issues experienced within the Sefwi Akontombra District in relation to cocoa purchasing were identified to be theft/robbery incidences and insecurity associated with the haulage of the cocoa beans. The district recorded $31 \%$ insecurity issues including stealing of cocoa beans from sheds operated by PCs, robbery attacks and stealing of monies meant for purchasing cocoa beans by PCs, PCs and farmers misunderstandings among others in the year 2015 (District Police Office, 2016). Between January and February, 2016, when the study was conducted, approximately $17 \%$ of the total insecurity issues including theft of cocoa beans, attacks on PCs etc. were reported to the District Police Service (District Police Office, 2016). These statistics according to the office of the District Police Commander fall below the actual number of insecurity issues recorded in relation to cocoa purchasing as most cases related to cocoa purchasing are not reported to the police. From the statistics, it can be observed that insecurity issues related to cocoa purchasing form a considerable percentage of the total number of insecurity issues recorded in the district.

\section{Theft of Cocoa Beans and Funds}

Stealing of purchased cocoa beans and funds meant for purchasing cocoa were reported as a major insecurity issue. Approximately, $80 \%$ of the PCs interviewed indicated that they have had part or all cocoa beans they had purchased stolen from their cocoa sheds. The breaking into sheds owned by individual PCs at their stations as a result of the absence of security to guard such facilities was a common phenomenon. Stealing of purchased cocoa beans at the company's warehouse was further reported. This was however considered as not a regular occurrence and mostly attributed to internal conspiracy. Robbery attack on PCs by robbers who do away with funds meant for purchasing cocoa was also common in the district. The study found out that during peak cocoa purchasing season (mostly in September and October) about eight PCs per month come under such ordeal where they are attacked and their funds taken from them. The protection of funds and purchased cocoa beans at the stations where PCs operate was reported as the sole responsibility of the individual PCs. This implies that very little importance is attached by OGL to the security associated with cocoa buying and storage at the cocoa growing areas. 


\section{Cocoa Haulage Trucks Attacks}

A number of insecurity issues were recorded in relation to the haulage of purchased cocoa beans. There have been attacks on haulage trucks (especially the flat body type) transporting cocoa beans to the port during the night. Such attacks were reported at least once a month during peak cocoa purchasing seasons. During the 2015/2016 main cocoa season for instance, an incidence was recorded where a vehicle transporting cocoa beans to the port was attacked by robbers when the driver stopped to rest at night.

The robbers made away with 200 bags of cocoa beans and drove the vehicle with the remaining cocoa beans to a different location in the Ashanti Bekwai. This incidence was reported to have taken place on the Kumasi-Nyinahin road. This clearly shows the lack of security measures during cocoa beans evacuation by OGL. It is strange that OGL spends so much funds in purchasing the cocoa beans but neglects the protection of the beans. It can also be deduced that OGL has not come to terms with the realities of insecurity issues associated with cocoa purchasing in the West African subregion. Haulage of the beans has not been given the necessary attention in terms of the security and safety measure. The study further found out that the haulage trucks that transport purchased cocoa beans to the port were not owned by OGL. They are owned by private individuals who have registered with OGL to evacuate their purchased cocoa beans. This may account for the neglect of security measures on the part of OGL in transporting the cocoa beans because the safe transportation of the cocoa beans to the port is regarded the sole responsibility of the registered private transport drivers. At the time of the study, OGL had ban all private drivers transporting their purchased cocoa beans to the port from driving at night as a remedy to the security issues faced in transporting the cocoa beans. This remedy can be considered as superficial and ad hoc and cannot address the challenge.

\section{Security Arrangements and Mechanisms}

Information from key informants at OLAM Ghana Limited and the office of the District Commander of Police in the Sefwi Akontombra District indicates that there are no specific security arrangements and mechanism in place as far as cocoa purchasing in the district is concerned. A Chief Inspector of Police at the office of the District Commander of Police at Akontombra categorically stated that their outfit does not have any specific arrangement with any of the LBCs including OGL operating in the district. It was found out that the police are only involved in aspects of cocoa buying, storage or transportation in the district when there is a specific security problem. The absence of security mechanisms during peak cocoa purchasing periods coupled with the non-involvement of the Ghana Police Service in cocoa purchasing activities to a greater extent account for the myriad insecurity issues associated with cocoa purchasing in the district.

\section{Access Roads and Insecurity}

Some of the roads linking the cocoa growing towns are very bad and their conditions facilitate robbery. This is because the robbers attack the haulage trucks at sections where the condition of roads is bad. The condition of the entire feeder roads linking the major cocoa growing towns in the district are is bad and there is currently no plan for improving them. The district does not have an office for the Department of Feeder Roads and the maintenance of such roads are not considered a top priority of the District Assembly. The maintenance of 
the feeder roads within the district is subcontracted to unskilled personnel at the district level and it is done as and when the feeder road becomes unusable. This is a major challenge as far as cocoa purchasing is concerned because the bulk of cocoa grown in the district takes place in the interior which is linked by feeder roads. The stretch of road between Akaakrom and Besibema in the district was considered the riskiest section that is prone to constant attacks on haulage trucks.

\section{CONCLUSION}

The study was undertaken to understand the issues of insecurity associated with cocoa purchasing activities in the Sefwi Akontombra District of the Western Region, Ghana. From the findings of the study, it can be concluded that security arrangements with regards to cocoa purchasing, storage and transportation is not paramount among key stakeholders in the Sefwi Akontombra District. This reflects in the absence of security arrangements during peak cocoa buying seasons in the District and adequate security measures by the OLAM Ghana Limited, the case studied. In line with this, the following recommendations are made:

- The Ghana Police Service, the LBCs and other key stakeholders in the district must meet to agree on security arrangements for handling funds and transporting cocoa beans to ensure safety and security during peak cocoa purchasing periods. The Police Service must initiate this all-important task to mitigate if not to completely do away with the insecurities associated with cocoa purchasing in the Sefwi Akontombra District.

- OLAM Ghana Limited must make the issue of insecurity at the local stations where PCs operates a top priority of the company. Security at the stations where
PCs operates must be a shared responsibility between the company and the individual PCs.

- Moreover, the company must assign police or private security personnel to vehicles transporting cocoa beans to the port. The safety of transporting cocoa beans to the port must not be entirely left to the private transport owners. This should be a shared responsibility between the company and the private transport owners to ensure the safety of the cocoa beans and the transport drivers.

- COCOBOD must extend its award of road contracts to cover the maintenance of key feeder roads in the district given that the bulk of purchased cocoa beans are transported via these roads.

- The piloting of a cashless system of purchasing cocoa in some cocoa growing districts must be applauded and accepted by all LBCs including OGL. This will eliminate the issues of robbery attacks on PCs.

\section{ACKNOWLEDGEMENTS}

The authors would like to thank the District Manager of OLAM Ghana Limited and the District Police Commander at Akontombra for their immerse support during the data collection stage of this study.

\section{REFERENCES}

Asante-Poku, A. \& F. Angelucci (2013). Analysis of incentives and disincentives for cocoa in Ghana. Technical Notes Series, MAFAP, FAO, Rome.

Afoakwa, E.O. (2014). Cocoa Production and Processing Technology. CRC Press. ISBN. 1466598247, 9781466598249

Asante, Y.; F. Nixson \& K.G. Tsikata (2000). The industrial sector policies and economic development. p. 246-267. In: 
Economic Reforms in Ghana: The Miracle and the Mirage. E. Aryeetey; J. Harrigan \& M. Nissanke (Eds). Africa World Press Inc.

Asamoah, M. \& F. Baah (2003). Improving research-farmer linkages: The role of CRIG. The $4^{\text {th }}$ International Seminar on Cocoa-Pests and Diseases (INCOPED), Accra, Ghana, 19-21 October 2003.

Baldwin, D.A. (1997). The concept of security. Review of International Studies 23, 5-26. British 'International Studies Association.

Binam, J.N.; J. Gockowski \& G.B. Nkamleu (2008). Technical efficiency and productivity potential of cocoa farmers in West African countries. Development Economics, 46, 242-63.

Creswell, J.W. \& R. Designm (2008). Qualitative, Quantitative, and Mixed Method Approaches. Sage. Los Angeles, CA.

Dzene, R. (2010). What drives efficiency on the Ghanaian cocoa farm? Working Paper. Ghana Institute of Management and Public Administration. Accra, Ghana.

DPO (2016). Sefwi Akontombra Station Diary. District Police Office, Sefwi Akontombra, Ghana.

Ecobank (2015). Cocoa mixed outlook for West Africa's 2015/16 cocoa season. Middle Africa Briefing Note, Soft Commodities, Cocoa. Ecobank Research, United Kingdom.

Gallie, W.B. (1956). Essentially contested concepts. Proceedings of the Aristotelian Society, New Series, 56, 167-198.

GSS (2010). 2010 Population and Housing Census. Ghana Statistical Service, Accra, Ghana.

GSS (2014). 2010 Population and Housing Census: District Analytical Report, Sefwi Akontombra. Ghana Statistical Service, Accra, Ghana.
Kumar, R. (2011). Research Methodology: A Step-by-Step Guide for Beginners. $3^{\text {rd }}$ Edition. SAGE Publications Ltd. London.

Liven, A. \& I. Baud (2007). Marketing reforms in Ghana's cocoa sector (Partial liberalization, partial benefits?). Background Note. Overseas Development Institute.

Lundstedt, H. \& S. Pärssinen (2009). Cocoa is Ghana, Ghana is cocoa: Evaluating reforms of the Ghanaian cocoa sector. Minor Field Study Series: Nationalekonomiska institutionen Vid lunds universities.

Schäfer, P.J. (2013). Human and water security in Israel and Jordan. Environment, Security, Development and Peace. 3, 5-18.

SADA (2014). Location and Size of District. Sefwi Akontombra District Assembly, Ghana.

SWAC/OECD (2011). Emerging good practice in combating the worst forms of child labour in West African cocoa growing communities. Report. Sahal and West Africa Club.

UNDP (1994). Human Development Report 1994. New Dimensions of Human Security. Oxford University Press. Oxford, New York.

Williams, P. (2008). Security studies: An introduction. Routledge, London-New York.

WCF (2014). Cocoa Market Update. World Cocoa Foundation. Washington DC.

Wolfers, A. (1962). National security as an ambiguous symbol. In: Discord and Collaboration. sEssays on International Politics. A. Wolfers, (Ed.). John Hopkins University Press. Baltimore.

$$
* * 0 * *
$$


Obodoi et al. 